\title{
Development and the Yucatec Maya in Quintana Roo: some successes and failures
}

\author{
E. N. Anderson ${ }^{1}$ and Barbara Anderson ${ }^{2}$ \\ University of California, Riverside, USA \\ Frontier Nursing University, USA
}

\section{Introduction}

In this article, we explain why certain agricultural development and health promotion efforts have succeeded and failed in Maya communities in the Yucatán Peninsula of México (Fig. 1). In questioning the successes and failures of development programs, we find that one important predictor of development success is supply and demand relationships: where there is an agricultural market, the Maya have worked to develop supply it; where there is no market, traditional subsistence methods perform better than introduced agricultural schemes and techniques. Government or international help is needed to establish markets, and to provide expert knowledge of how to mobilize for them and to connect with them. Some important successes for local people, in terms of livelihood enhancement and the creation of economic opportunities, have followed.

Agricultural systems in the region are adapted to shallow and fragile soils, and susceptibility to frequent droughts, typhoons, and pest outbreaks. They have changed to incorporate new ideas that fit with the basic commitment of farmers to shifting agriculture, based on maize as the staple, and over one hundred minor crops. The Maya show a thorough understanding of the Yucatán environment, and use a range of resources and techniques flexibly, allowing for fine-tuning in particular situations.

The economy of market opportunity is, however, affected by international subsidies. We question the effects of "neoliberal" policies, presenting examples from Maya communities centered on the town of Chunhuhub, Quintana Roo. Neoliberal economic policy has resulted in a reduction, but not a complete cessation, of government assistance to local and small-scale enterprises. At the same time, large-scale multinational firms operating on the Peninsula are given large direct and indirect subsidies by their home governments and by commodity-producing nations. This paradox results in unfair competition for local enterprises, and this is a finding shared with other studies of the political ecology of the region. Finally, we reflect on whether truly 'free' markets - in the sense of local grassroots enterprise being given something like a level playing field to operate alongside external actors — could be an improvement for local people.

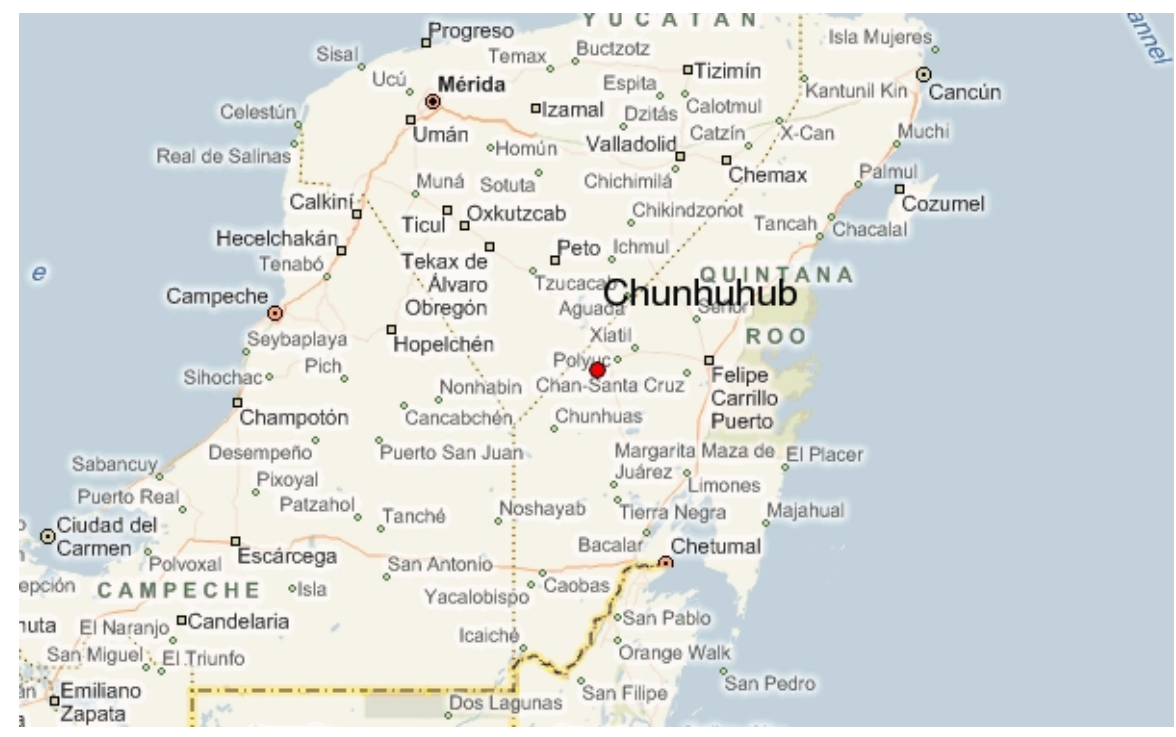

Fig. 1. Chunhuhub, Quintana Roo, México. Source: http://www.weather-forecast.com

\footnotetext{
${ }^{1}$ Eugene Anderson, Professor Emeritus, Department of Anthropology, 1334 Watkins Hall, University of California Riverside, CA 92521, USA. gene "at" ucr.edu, http://www.krazykioti.com. We are grateful to Simon Batterbury, David Ellerman, three anonymous reviewers and Miguel Popoca Guerrero and for help and advice with this paper.

${ }^{2}$ Barbara Anderson, Director, Doctor of Nursing Practice program, Frontier Nursing University, P.O. Box 528, 195 School St., Hyden, KY 41749, USA.
} 


\section{Methodology}

To explain the failures and successes of agricultural development taking place in Maya society still wedded to traditional resource management and belief systems, the authors have conducted anthropological research largely in and around Chunhuhub, a large town in west-central Quintana Roo (Fig.1). The first author began research here in 1989, and has made semi-annual visits since then, with annual visits since 2001. Three periods of research lasted several months: six months in 1991 and again in 1996, and four months in 2001. ${ }^{3}$

Research has involved participant observation (see Bernard 2006) and detailed interviewing. Specialized research over the years has been made on ethnobiological techniques, notably through field surveys and walks, and frame elicitation (Bernard 2006; Frake 1980), collection of economic data and statistics when possible, and botanical specimen collection. Specimens are deposited at the University of Yucatán, Mérida, and ECOSUR, Chetumal, Quintana Roo. Agricultural studies involved walking the fields with farmers, observing, photographing, assisting, and asking about particular practices and decision-making (cf. Gladwin 1989). The authors worked in Spanish, with use of Maya where possible (largely for dealing with plant and animal names, and agricultural terminology). ${ }^{4}$ Interviews was also carried out with government development workers, local university and school personnel, urban middlemen and processing businesses, and in the United States with Maya in California; woodworkers and tropical products importers in California; and Mayanists everywhere. Insights below are derived in significant measure from following Maya products along the chain from the villages to cities in the Yucatán Peninsula or even to the United States.

\section{Maya agriculture and traditional livelihoods}

The Yucatec Maya have been cultivating the Yucatán Peninsula for about 5,000 years. For almost 3,000 years, this cultivation has supported a society with towns and many components of a state system. For about 2,000 years, the Maya have had a defined elite, and sophisticated art and writing (Sharer and Traxler 2005). The Maya collapse in the $9^{\text {th }}$ and $10^{\text {th }}$ centuries led to a decline in population and settlement. Cities in the central lowlands of the Peninsula were abandoned. The causes of this collapse are still disputed but involved excessive use of resources (especially deforestation), drought, warfare, and political disunion (Demarest 2004; Webster 2002). Cities like Mayapan and Chichen Itza survived the collapse, however, and continued to flourish until the Spanish conquest which began in the early $16^{\text {th }}$ century.

Maya civilization was supported by highly sophisticated farming systems. The agro-ecosystem has evolved to use the environment of the Yucatán Peninsula efficiently. ${ }^{5}$ This involves, first of all, 'using everything lightly'. This generally means that there is every incentive to preserve the whole system intact, and no incentive to destroy any one resource. The staple food is maize. Under Maya conditions it yields around $1,000 \mathrm{~kg} / \mathrm{ha}$ or more, up to 2,000 kg/ha in good conditions (Anderson 2003, 2005; Tuxill et.al. 2010). While this is low by USA standards, these are high yields for tropical locations with poor soils. However, the crop is very susceptible to droughts, floods, and hurricanes. These are all common in the Yucatán Peninsula, so people must often fall back on root crops such as manioc, sweet potatoes, and makal (Xanthosoma yucatanense), and several other other back-up staples.

Crops are menaced by extreme heat and dryness in spring and early summer, extreme storminess with occasional hurricanes in late summer and fall, surprisingly cold midwinters, and great fluctuations from year to year. The land is rocky, with shallow soils. The forest is diverse and lush but thorny; a local proverb says, with some exaggeration, that "every plant has thorns and every animal bites or stings." The soils of the Yucatán vary from extremely rocky and barren to light but fertile. In wet areas, the variation is from acid soil to rich, fertile alluvial loam. Ruin mounds indicating prior settlement provide good indications of where the good soil is, and are quite good places for planting.

The Maya are experts at assessing soils and have an extensive soil terminology (Anderson 2005; Terán and Rasmussen 1993). In the traditional agricultural system still used in the areas described in this article, maize grows in swidden fields. It is cut in midwinter, the residues are burned in the early part of the dry

\footnotetext{
${ }^{3}$ Otherwise, visits have been for a day or a few days. The second author has made short visits since 1998. We have also conducted research in Presidente Juarez (about $40 \mathrm{~km}$ from Chunhuhub) and shorter visits in several other towns, especially Xpichil, Margaritas, and Polyuc (with regular detailed visits since 1991), with much briefer visits to Naranjal Poniente (many short visits over time) and Tres Garantias (one day in 2001).

${ }^{4}$ We worked with a number of research assistants, especially Felix Medina Tzuc and Andres Sosa in Chunhuhub and Maria Aurora Dzib Xihum de Cen in Presidente Juarez.

${ }^{5}$ See longer accounts in Anderson 2003, 2005, 2006, 2010a; Anderson and Medina Tzuc 2005; Faust et.al. 2004; Fedick 1996; Gómez-Pompa et.al. 2003; Herrera Castro 1993; Kintz 1990; Martinez Reyes 2004; Terán and Rasmussen 1993; Terán et.al. 1998; Toledo et.al. 2008; on the culturally similar Izaj Maya see Atran 1993; Atran et.al. 1998, 2004.
} 
season before fire can spread, then cleared of burned timber and planted. Fields are replanted the next year, then abandoned to grow back for anywhere from 5 to 50 years, depending on soil fertility.

The Maya farming system remains the only viable one across most of the Yucatán Peninsula. The Yucatec grow a wide range of crops, and use an even larger number of wild products (Anderson 2003, 2005; Gómez-Pompa et.al. 2003; Terán et.al. 1998). Maize is often intercropped with beans, squash, and other foods, and dooryard gardens with dozens of species provide a great deal of the agricultural produce. But maize is dominant. Sweet potatoes, several species of beans and squash, manioc, tomatoes, and chilies are also important. Fruit is widely grown, not only for food but as the main commercial enterprise in the area. Oranges, other citrus, mangoes, coconuts, papayas, mameys (Pouteria mammosa), watermelons, and other species are grown for sale, and dozens more species are eaten locally (see data in Anderson 2005). People will experiment; for example with grapevines and apple trees, which do not fruit in the tropical climate, but which are points of pride to their owners. Wild foods are important famine staples, and include a huge range of roots, fruits and shoots.

An emerging problem is excessive shortening of the swidden cycle, caused by rapid rural population growth. This is not yet a major problem in most of Quintana Roo, though some areas near large towns are suffering. It is a far more serious problem in Yucatán state and parts of Campeche, where many areas are experiencing degrading land cover (Turner et.al. 2003). Forest resources are especially hard hit.

Since Spanish colonization in the early $16^{\text {th }}$ century, outsiders have tried monocrop cultivation of cotton, sugar, rice, sesame, and dozens of other crops. Most of these efforts have failed, even industrial-style cultivation of maize. Exceptions include fruits and henequen, an agave used for hard fibre. Henequen flourished as a monocrop because it is native to the Yucatán landscape and perfectly adapted to it. Unfortunately, Yucatán's henequen industry declined with the invention of nylon, as well as with the development of cheaper henequen production in Africa and Brazil (see Baños Ramirez 1989, 1990; Benitez 1986). Henequen still grows and is occasionally used for fibre, and also for a cheap form of mescal liquor and other purposes (source: field research).

The ability of the system to add and incorporate new crops is important. The Spanish brought hundreds of species from Europe, the Near East, and later southeast Asia (via the Philippines-administered as part of México in Spanish colonial times). The modern world has introduced yet more. The South East Asian and Polynesian medicinal fruit noni (Moringa citrifolia, Rubiaceae) was introduced around 2004 via indigenous person-to-person channels. It is believed to be of Indonesian origin but has diffused widely, and is used to treat diabetes. It is now grown in hundreds of gardens in the area studied around Chunhuhub. The Maya also learn to recognize and name new weeds, and sometimes find uses for them.

Almost 900 species of plants known to the Yucatec are listed in the major compilation by Arellano Rodríguez et.al. (2003), and more can be added since that volume was published (it is already the largest ethnobotanical inventory documented for any small indigenous group in the world). Most species have recorded Yucatec names and uses. Foodways are appropriately varied and complex to take account of all these opportunities (Staller and Carrasco 2010). Especially noteworthy are medicinal plants, both tame and wild. Over many years we have recorded 350 medicinal species in the area, and other investigators have recorded comparable numbers from other communities in the Yucatán. Tests have shown that many of these plants are effective antibiotics, antifungals, analgesics, and anti-inflammatories. Some cure itches, rashes, canker sores, and the like more effectively than local drugstore remedies. Plants are used for everything from childbirth (B. Anderson et.al. 2004) to fungal skin infections.

Eek' or tinto, also known as logwood (Haematoxylon campecheanum), produces a black dye widely used even today and extremely important worldwide until the rise of synthetic dyestuffs. Since this change in markets occurred, the cut trees have sprouted back as dense thickets of shoots, and formed impenetrable jungles where jaguars and jaguarundis hold out.

Hunting is a local tradition. People who have small gardens, or who need to sell the animals that they raise to earn cash, very often lack iron and sometimes protein in the diet, and are hungry for meat. Wild game include deer, paca, agouti, game birds, and more (Anderson and Medina Tzuc 2005; Escamilla et.al. 2000; Greenberg 1992). Powerful cultural rules were traditionally used to keep hunting within sustainable and manageable levels (Anderson and Medina Tzuc 2005; Martinez Reyes 2004). These traditional rules sustained hunting regimes until the last two or three decades. They were successful locally, but unfortunately they are now breaking down. Some families have recently taken to commercial hunting, which devastates the game, and even with traditional controls in place the population density of many villages is enough to put intolerable pressure on diminishing animal populations and large animals have been over-hunted in areas around large towns (including around Chunhuhub). The system is slowly adjusting to the new shortage and meat is fairly common in the Quintana Roo diet, because every homegarden is well stocked with chickens. Most have ducks and pigs. Some have sheep and cows and even tamed peccaries and deer (Anderson and Medina Tzuc, 2005). 
Trees in the landscape are 'managed'. Stands in farmed areas are dominated by leguminous species that fix nitrogen and rapidly restore soil fertility. Thousands of years of swiddening has led to gradual takeover by leguminous trees (notably species of Acacia, Leucaena, Lysiloma, and Piscipula), that now dominate second growth in most of the area. Selective cutting also leaves useful species like the chicle tree (Manilkara sapota; see Mathews 2009), valued for fruit as well as for chewing gum production (Redclift 2004). Palms, especially the $x a^{\prime}$ an used for thatch, are also selectively preserved, as are many other species. Trees killed and hollowed by burning become homes for bees and game animals, and are therefore protected. The Maya house is a good example of a locally made item with low ecological impact (Anderson 2005). It is made of local hard woods, often harvested from areas that will be cut for milpa. It is thatched with palm fronds from species of Sabal.

\section{Traditional knowledge and morality}

The traditional system described above requires a great deal of knowledge of the environment (Anderson 2005; Martinez Reyes 2004). The Maya farmer must know dozens or hundreds of plants and animals, including all their uses, their seasonality, methods of collection and processing, and problems with obtaining and managing them. Maya farmers are exquisitely attuned to soils, fire control, seasons, the weather and other changes. They monitor the actions of their neighbors, and accommodate accordingly. They often act in concert to protect a resource from overuse or abuse-making individuals cut firebreaks, for instance. They maintain trails, cut small firebreaks around valuable seedling trees, preserve wild beehives and ant nests, and watch for the growth of anything edible or usable in the forest. A Maya forest is never really 'wild'. It is constantly being monitored. No patch of forest goes for long without hunters, medicine collectors, honey-seekers, and other foragers. All this depends on extensive practical knowledge, both general and specific in nature.

No one person can have all of this knowledge, so information is distributed in the community. People are proud of particular expertise they might have. According to interest and experience, one might be an expert hunter, or bean farmer, or beekeeper, or curer, or religious officiant (hmeen), logger, or other specialist. All working adults in the community know who these people are and where to find them, and they are frequently consulted. This stands in marked contrast to approaches that view culture as comprising knowledge that is universally shared and understood across a social group. Culture is, rather, distributed cognition. A community can know dozens of times as much as an individual could possibly learn.

The management of resources depends also on conceptions of morality, and these are maintained by religious belief (Anderson 2005; Martinez Reyes 2004; Terán and Rasmussen 19936). Pre-Columbian Maya traditions have integrated well with Catholicism, and more recently, to a lesser extent, with Protestantism. Traditional ceremonies such as prayers for rain (ch'a chaak) and ceremonies to pray for or to thank the gods for good harvests (loh) were common in former times. Non-Maya priests and pastors in both Catholic and Protestant churches have tried to overturn these ceremonies, with negative results for the management system. Our research indicates that without a supportive belief in forest spirits, field spirits, and other local supernatural beings, people are tempted to break rules against overhunting, over-collecting, and careless burning of fields. Religious belief restrains even quite desperate people from rule-breaking, even when they are alone, unobserved, and safe from being caught.

One of the communities in our sample told a visiting Catholic priest not to come back when he tried to interfere with their land-oriented ceremonies. Representing land management in religious terms is absolutely fundamental in Maya culture (Faust et.al. 2004; Redfield and Villa Rojas 1934). ${ }^{7}$ Religion and ceremony are necessary to bring people together, get them to work together, and to motivate them to keep their rules. The landscape and resource management rules, unlike many religious customs in this world, are hard-headed pragmatic ones.

Many or most Quintana Roo Maya love and care for the forests. As our field assistant and coworker Felix Medina Tzuc said: "Me encanta la selva, me encantan las arboles" ("the forest enchants me, the trees enchant me"). We have heard dozens of similar statements. ${ }^{8}$ Care, like the maintenance system, is represented in and maintained by religious belief. Some Hispanic Mexicans, by contrast, tend to idealize urban life, looking down on agriculture, and sharply separate religion from secular pursuits. In times past

\footnotetext{
6 There is broad agreement among these three very different sources.

${ }^{7}$ Redfield and Villa Rojas (1934) offer a classic, thorough account that still has considerable validity today.

${ }^{8}$ Quintana Roo was deforested, to a debatable degree, in the Classic Maya period, 1,500 years ago. The forest regrew after $900 \mathrm{CE}$, and has been substantially preserved since (Sharer and Traxler 2005; Turner et.al. 2003). Whitmore and Turner (2000) take a strong view of the early deforestation, but subsequent work seriously questions the universality of the trend; see McAnany and Gallareta Negrón (2010), McAnany and Yoffee (2010) and Wright (2006). Thus the relevance of earlier deforestation to the present is not clear.
} 
some had little ideological reason to care for landscapes (see Simonian 1995). This is changing fast, though not without major problems (Haenn 2005).

\section{Change, failure and success}

Since the late 1980s we have observed major changes in the region. The Maya of Quintana Roo have generally become more prosperous, but the process has been erratic and uneven. Development plans have come and gone in the area. Chunhuhub residents usually reject outside plans, aware from experience that they often fail. In this section we explore some of these failures and successes, focusing on agriculture and to a lesser extent on health promotion.

A broad assessment of local livelihood systems shows that some people still choose to concentrate on subsistence farming while commercial cropping is widely practiced, so a discussion of efforts to modify agricultural performance is still relevant. Unfortunately, our informants report diminishing rainfall (as occurred in previous warming episodes including the Medieval Warm Period) and more frequent storms in recent years, making agriculture more problematic today than it was twenty years ago. Crop failures are more common over this period, because of these droughts and storms. For example, the maize crop in the community of Presidente Juarez, which is poorly situated for agriculture except in good years, ranged from about $50 \%$ of the long term average to complete harvest failure from 2005 to 2010 (source: field assistants).

\section{Failed or unsuccessful projects}

Many plans fail because of biological and agronomic limits. One frequent failure involves attempts to convert land to pasture for cattle (see Painter and Durham 1995, for cases across Latin America). In tropical México, millions of acres of highly productive forest have been converted to poor-quality pasture land, which can degrade into desert depending on management regimes and rainfall. In Quintana Roo, there are some natural grasslands that are excellent cattle-raising country. But some attempts to clear forest for grassland have been ill-advised and sometimes disastrous, because good grass requires moisture-holding, non-acid soil. Excessively drained areas, areas with acid soils, and excessively wet areas produce superb and very valuable forests but poor grassland. Many such areas were cleared for pasture, and we have observed many, covering thousands of acres across the study villages that became degraded instead, until trees could regrow. The Maya clear and burn small cornfields, which promptly grow back to healthy forest, but the huge areas cleared for pasture burn too easily. They were usually cleared too thoroughly-sometimes with bulldozers, scraping down to bedrock. They are too large for easy seeding by hand. Another chronic problem for stockraising is the abundance of jaguars in more remote areas. They attack livestock and have ruined stockraising in one of the study villages, Presidente Juarez. Nonetheless small-scale rearing of the tough local cattle is successfully practiced, especially in fertile roadside areas where pasture grass can be grown and where livestock can be integrated into orchard and crop raising.

All manner of non-native crops have been tried in Quintana Roo and other Yucatán Peninsula states, with varying success. Sugar succeeds, but not well, in the most fertile areas; Chunhuhub once grew large quantities, but abandoned it long ago. Elsewhere in the Yucatán Peninsula, rice failed because of poor soil and high costs. Sesame, commercial maize, indigo, cotton, and several vegetable crops failed because of low yields. We have studied several projects for commercial production of tomatoes, chiles, and similar vegetables. However, diseases and pests rapidly build up in the tropical environment. Recently, commercial agricultural schemes have often involved artificial fertilizers and pesticides. Fertilizers can run off the rocky fields and contaminate the water supplies. Pesticides also kill local insect-eating creatures and thus lead, paradoxically, to pest outbreaks; overuse of pesticides led to huge numbers of whiteflies in the 1990s, that destroyed commercial cropping of chiles and tomatoes in the major farming areas of Yucatán (Keys 2004).

One idea popular in the 1980s was package loans for agriculture, involving loans that required the farmers to use pesticides and fertilizers according to best practice. The Maya were in no position to risk capital, and as already mentioned, found that the pesticides and fertilizers were generally counterproductive in their situation. The packages disappeared by the late 1980s and currently farmers in the study villages only use small amounts of chemicals in highly localized doses.

Many other plans surfaced at local farmers' agricultural fairs held in the larger towns. These had some direct or indirect influence on farmers around Chunhuhub. Weobserved schemes to popularize local handicrafts. These seemed sensible but Chunhuhub Maya are not large producers. Honey production, both from European honeybees and from native stingless bees (Melipona becheii), was also promoted. Honey was marketable outside the region; the Yucatán Peninsula produces superb honey, and the Maya love beekeeping. The Yucatán is acknowledged as a major producer, and provided up to $15 \%$ of global supply until recent 
years. Chunhuhub produced large quantities. But today China has taken over as the top producer, and African bees and parasitic mites (Varroa and other spp.) have reduced local production considerably. ${ }^{9}$

In other communities, including Yaxcaba and neighboring towns in Yucatán state, small-scale commercial vegetable raising without much outside input was promoted. A denser population meant a larger market (source: field research). Attempts were also made to develop velvetbean as a cover crop (Juan Jimenez-Osornio, personal communication; cf. Buckles 1995) and, when that failed, to use chopped-up vegetation as mulch (John Tuxill, personal communication). Mulching reduces evaporation and increases soil quality. But the Maya found little value in these techniques, since they added extra work to an already laborintensive agricultural system. In addition local farmers were suffering 'project fatigue', partly because their homegardens were already fertile and bean-filled, while their shifting fields were not really worth the added effort and expense. By contrast, mulching has worked very well in other areas of Latin America.

Raising rabbits (cunicultura) has often been tried in México and elsewhere. Thomas Dichter in Despite Good Intentions (2003) tells a mordantly funny story of failed rabbit-rearing in West Africa, where the rabbits immediately died of tropical diseases. They survive in Mayaland - they are native cottontails-but are less successful than the chickens, pigs, goats, ducks and turkeys that already make a Maya homegarden a meat source, because they are rarely killed.

Medicinal herbs have been commercially produced in Quintana Roo, and could be produced on a large scale since they are saleable. We found that many are taken by migrants to the United States for the south Mexicans working there. But several attempts to commercialize medicinal herbs in the province have failed, partly because of hurricane risks, partly because it is still cheap to collect wild herbs, but mainly for the common reason that no one thought to develop marketing channels. This is a common theme.

The lesson is that in a realm of largely subsistence production, long-range marketing is absolutely necessary for any commercial rural activity to succeed. Most Maya do not have the capital nor the experience or contacts to reach markets on a wider scale. Even marketing to local cities has been somewhat problematic. The long-range marketing necessary for most commercial undertakings would require outside help. Chunhuhub is a very remote community, of around 6,000 people, and there are many settlements closer to the urban markets where vegetables and other products may be sold. South México has only recently acquired a large urban sector. Still more recent is its emplacement in the world economy-first as a henequen supplier, more recently as a tourist destination. Marketing to well-to-do people in, or from, other countries was not a normal part of life until very recently. ${ }^{10}$

In the meantime, the ejido system of communal landholding and collective management is facing change. Alterations to Mexican law in 1993 allowed privatization of ejido land. The Maya of Quintana Roo, like many others in México, resisted this for a long time (Perramond 2008). Privatization finally came to Chunhuhub in 2005 when the ejido membership voted to implement the 1993 law. Since this time, many ejido members have sought work in urban areas, becoming everything from computer programmers to law students. Others wanted more chance to be flexible and independent in their land management. They have also moved more into commercial production: livestock and orchards.

\section{Successful projects}

Success is defined as the ability to raise local incomes and levels of living, largely as assessed by the people themselves, but also visible in clothing, house type and maintenance, education levels for children, and material possessions. Monetary income is hard to assess and very often less irrelevant, since this is still largely a subsistence economy despite the new occupations mentioned above. Food, housing, and medicine are largely produced by families. In most households, cash is derived from sales of fruit, livestock, and other farm goods, and from odd jobs and transient employment; it is used most commonly for clothing, consumer goods, and education. Residents have done much through their own initiative. Local enterprises have erratic histories, but some of them have succeeded and we discuss them here. ${ }^{11}$

The innovations in Chunhuhub have focused on new products. Most interesting was the noni tree noted above. The tree is used in Hawaii for treating many ailments, but the Maya know it especially as a Type II diabetes reliever. It appears to work; at least the Maya swear by it, but they always use it with Cecropia leaves and other local traditional remedies, so cannot really factor out which plant is really responsible for the truly striking relief they often enjoy. Small-scale commercial raising of noni has blossomed in Chunhuhub in

\footnotetext{
${ }^{9}$ A full account of the honey economy is found in Anderson and Medina Tzuc (2005).

${ }^{10}$ Extremely successful vegetable gardening is practiced by several families in town, but almost everyone grows their own vegetables so there is little internal market. Mahogany and other precious timber was produced on a small scale, but was only sold nationally until the 1990s.

${ }^{11}$ Rani Alexander (2006) illustrates the notable adaptability and dynamism of "traditional" Yucatec society.
} 
less than ten years. Other new crops, such as South American passion fruit, have also entered the area and expanded.

Another newcomer is sheep. The Yucatec Maya did not traditionally keep sheep, which they call "cotton animals" (h-taman), in spite of Colonial Spanish introduction. As of 1991, Chunhuhub had a few sheep, in the care of a single shepherd. From the late 1990s, however, mutton was saleable. There was tourist demand in and around Cancun and demand by mutton-loving Central and North Mexicans who had moved to the area. So more and more Maya have added tough, heat-resistant tropical sheep to their dooryard gardens. Again, local initiative responds to market opportunities.

Overall, there has been a progressive rise in local prosperity resulting from sale of fruit, ornamental plants, thatch, nonprecious woods, medicinal herbs, and many forest products. Chunhuhubians are also extremely good at finding part-time jobs. We have recorded over 60 such informal part-time occupations from cake decorating to acting as clowns at parties. Obviously, the Chunhuhubians could do much more, and do not always succeed in their endeavors, but they have a good track record overall compared to the efforts of externally imposed schemes.

By far the major planned 'success' was the introduction of mechanized agriculture around 1980. Most of the Yucatán Peninsula is limestone with very shallow soil, unsuitable for agriculture, but along the rim of the central hill country are valleys with deep, rich alluvial soils washed off the hills. Only about 5 percent of Chunhuhub's land is in this category, but it is concentrated in one broad and level plain very near town. With mechanical pumps to bring up underground water and a tractor to pull a plow, this land can be productive. For the first dozen years of the agricultural project to exploit it, however, the pumps or the tractor were often broken, with spare parts almost impossible to find. By the mid-1990s the machinery was more reliable, and by 2000 the mecanizada was in full operation most of the time, helping to produce maize, watermelons, tomatoes, citrus, mangoes, and other crops. And yet, the one tractor was used collectively. Fields were small (typically 1 ha or less) and often fallowed to pasture. The maize was often a mix of híbrido (commercial hybrid) and criollo (local) varieties. Diversity in maize varieties endures, but is rapidly narrowing as farmers abandon the rarer criollo varieties (Tuxill et.al. 2010). The Maya report that hybrids only perform well under good to ideal growing conditions.

Another major success was the idea of corredores cítricos (citrus corridors), created in the late 1980s. This was a period of considerable activity since México's dominant political party, the PRI, felt seriously challenged for the first time in its history; it finally lost the Presidency to Vincente Fox in 2000. The PRI was desperately trying to earn support through offering project aid. This worked well in Quintana Roo; the projects sometimes succeeded and the PRI stayed in power there. For the citrus corridors, a strip 1 hectare wide was cleared along some of the highways in southern Yucatán and neighboring Quintana Roo, and the government funded local people to plant citrus there. Oranges in the area yield about $1615 \mathrm{~kg} / \mathrm{ha}$, not high by world standards but far from insignificant (source: field data). Irrigation was developed where necessary with more government funding. The idea was to plant oranges and use the fruit to make juice concentrate. A huge plant was set up at Akil, Yucatán. As happens so often, the government had given no thought to marketing. According to our informants, the juice concentrate cost twice as much to produce as that from Brazil, and in any case everyone in southeast México has access to cheap fresh citrus already. Thus the project failed to develop concentrate as a commercial success.

The Maya soon learned that there was a huge market for fresh oranges and orange juice in Cancun, Merida, and other nearby towns. They found and accessed this market by themselves. Some towns already had fresh fruit marketing networks; others, like Chunhuhub, had to start from scratch, but did so immediately and successfully. The people of Chunhuhub found they could also use these channels to sell watermelons, avocadoes, mangoes, bananas, mameys, and so on, produced from homegardens and increasingly from the mecanizada. Fruit is now the town's major income source. These and more minor successes have stimulated the state government to help in providing Chunhuhub with a new market building and a new town hall. Local enterprise has added a restaurant and food stalls, among other services.

Also successful is the internationally well known Plan Forestal (Forest Plan) (Bray et.al. 2005; Freese 1997; Primack et.al. 1998). This is a federal and state project that began with a pilot scheme in the early 1980s, with backing from GTZ (German Agency for Technological Cooperation, now GIZ), to work with Maya communities to locally manage their forest resources through sustained-yield timber harvesting. Quintana Roo's forests are full of valuable timber, including mahogany (Swietenia macrophylla), and the Forest Plan focused on these lucrative species. Government foresters work with Maya villages and individual ranchers in sociedades civiles (for-profit associations) to develop forest management and conservation plans, forbidding indiscriminate logging. The communities pay a small fee, and the government provides top-quality scientific advice and some help with accounting and enforcement.

The Plan has worked well, both at conserving forest and providing better local incomes mostly because there was a pool of highly trained foresters and administrators (field data; see also Bray 2005). In the 1990s the main bilateral donor became the UK's DfID (Department for International Development). One community, Nohbec, has even satisfied the exceedingly strict German standards for sustainable forest 
management, and can export mahogany and other timber to Germany at a premium price. Even communities that are not part of the Plan have seen how successful conservation and sustainable management can be, and now try to act accordingly. However, the Plan Forestal ran into troubled waters as it aged; early commitment and enthusiasm began to be subverted by local dissention and political problems (Faust et.al. 2004; Haenn 2005; Klooster 1999).

The Plan also extended to game conservation and ecotourism, on a limited and experimental scale, with enough success to make further efforts highly desirable. The villages involved in the Plan also have game animals, medicinal herbs, and a wealth of birds and lizards that attract visitors. Small-scale ecotourism succeeded initially in Tres Garantias, well to the south of Chunhuhub, and could easily be developed more widely. $^{12}$

Chunhuhub has, by and large, not participated in the Plan Forestal, though it has been a headquarters town and has reaped some benefits. We followed the process of decision-making on forest management. At first the ejido drastically overcut precious species-mahogany, Spanish cedar, etc. - and faced an economic crash. This taught them better planning, and as more valuable trees reached commercial size, Chunhuhub managed its forests more sustainably. Attempts to grow plantations of cedro (Cedrela odorata) did not work well; tip borers made the trees grow crooked, and cedro grows so well by itself that plantations are unnecessary.

The worst problem facing commercial forestry has been the lack of any local value-added industry for using timber. Chunhuhub has a well-established sawmill that produces construction lumber, but the high value hardwoods have to be sent to the city mills for uncertain and often low-quality milling. This has much to do with international marketing structures, including high standards in the developed countries. Perhaps the best thing that could be done for rural Quintana Roo villages at this time is developing a value-added logging industry based on sustainable yield. Of course, value-added bootstrapping could also be done with non-timber forest products and with agricultural produce. Quality woodworkers could use Chunhuhub's wood. One can still see logs burned for lack of buyers, which would bring several thousand dollars if seasoned and brought back to southern California's quality woodworking trade. ${ }^{\text {B }}$ ENA (Ecovillage Network of the Americas) has researched this issue at length all the way up the supply chain, from Chunhuhub to the Quintana Roo cities and on to woodworkers in the United States. It appears that the problem was México's tight export policies combined with the difficulties of starting a quality wood-seasoning operation (requiring kilns, etc.) in Quintana Roo. Such operations did work sporadically over the years, and ENA interviewed the owners and also the owners of sawmills that could have entered the field. The problem was lack of local markets and lack of facilities for export.

The biggest and most important change in the last 10 or even 20 years in Chunhuhub is hidden on a back street at the east end of town: the new health clinic. Until 2007, primary health care services came via a tiny, increasingly shabby clinic in the center of town. Finally, after many local requests, a well-appointed, well-built comprehensive clinic was constructed. It has dental and primary health care services and health education, with posters lauding the virtues of breastfeeding, folic acid, and other health education issues. It is staffed by nurses and doctors fulfilling national service obligations. There is a local transport vehicle dedicated to the clinic, improving the management of trauma and emergency obstetrical situations. Yet weekend coverage can be slim.

We carried out a study on the parteras (midwives) in the region. We have published some of the heroic stories of managing these medical complications in hurricanes, before this clinic and reliable transport service were initiated (B. Anderson et.al. 2004).The parteras said that many young women think this role is not part of the "modern" world and are no longer interested in learning the necessary skills. Yet, the community lacks primary health care coverage on a 24-hour basis, particularly on weekends; roads still get closed by hurricanes, and there has been little local involvement in identifying and training youth for health careers. The parteras have always been there, but now a social vacuum is emerging as they age. This problem is one tiny component of the global shortage and aging of health professionals, particularly nurses, currently a top priority for programming by the World Health Organization (B. Anderson 2011).

While the Mexican government has done a commendable job of placing primary health care clinics in population centers of 5,000 people or more, there has been little local involvement in identifying and training youth for health careers in their own environment. Talented young persons are not encouraged to study nursing, pharmacy, and midwifery-all services that could be incorporated into the PHC setting in Chunhuhub. It is essentially impossible for residents to obtain education in these areas without moving to large centers where they can attend college; Chunhuhub is too far for commuting. ${ }^{14}$

\footnotetext{
${ }^{12}$ When the senior author visited Tres Garantias with biologists involved in planning, the project was only beginning, but tourists were attracted. Results since 2001 have been hard to find or monitor.

${ }^{13}$ Margaritas is a quite ecologically conscious community, in high forest well south of Chunhuhub. It has a handmade furniture industry that has been managed sustainably.

${ }^{14}$ Source: personal research, involving interviewing and following up students over two decades.
} 
One change in Chunhuhub's health scene has been the opening of a tiny, struggling center for traditional medicine in the former government clinic. This center is part of a small chain opened and run by a husbandand-wife team from central México, Enrique Gálvez Garcia and Columba Marín Martínez. They found Maya traditional medicine to be highly effective (cf. Anderson 2003-a book known to and used by them) and have developed many teas, salves, and other preparations, as well as a useful and well-produced booklet (Marín Martínez et.al. 2008). They also provide massage and have the services of one of the parteras on call. One hopes for great things, but previous attempts to commercialize traditional medicine in the Zona Maya have not done well; local families can do it for themselves, and visitors are few.

Another interesting success story has been the CEBETA school. CEBETA is a Mexican category of technical school roughly equivalent to American community colleges. The Mexican government generously provided one to Chunhuhub in the late 1980s. Assuming that a successful farm town like Chunhuhub would want agricultural training, it provided only that. However, the Maya wanted computer training. They persisted, and eventually it was provided. The school and its programs survived a major scandal in 1996, in which the community protested alleged abuses and secured both personnel and programmatic changes. Later a hurricane destroyed the computers; they were replaced, again at local insistence.

The Maya of Chunhuhub are self-consciously modernizing, and demand education. This sets them apart from many of the smaller communities in the area, which are far less interested in formal education. Chunhuhub is still reflecting its (re)settlement in the late 1940s by a particularly dynamic, intelligent, and upwardly mobile group of young men, largely of the Xool, Tun, and Pat families; these families are now well represented not only in local business ownership but in skilled work and professional circles all over Quintana Roo. ${ }^{15}$ Chunhuhub has become a major producer of mechanics, teachers, and similar educated workers, who have fanned out all over south México.

Unfortunately, this produces a brain drain of educated young men and women. In the American Midwest of our childhood, people often said of small farm towns: "Around here, anyone with any git-upand-go has got up and gone." Chunhuhub is undergoing the same process 60 years later, and constantly reminds us of that line. A surprising number of the best and brightest have stayed; of men we knew in their youth, years ago, Teodomiro Tun Xool now runs the town pharmacy, Andres Sosa teaches in the schools, Gabriel Medina farms with his father, and many other old friends are still there, making a decent living. But most of the educated have gone on, scattered all over México, teaching, working in businesses and government bureaus: working with computers.

\section{The marketing problem}

History shows that the government brings in new plans that are only sometimes successful. The people of Chunhuhub and neighboring communities find their own ways to succeed, either independently of the government (as with local livestock development and local small businesses) or by re-tooling, re-adapting, and retargeting government plans (as with oranges and with CEBETA's curriculum). Sometimes a successful plan is adopted in neighboring communities but not in Chunhuhub, but sometimes Chunhuhub finds ways to do the same thing without help-as in the case of forest management, where early mistakes led to sensible policies (Anderson 2005). One might hope for more consistency of plans but also more flexibility from the government, and more learning from the Maya to see just how a plan can be adopted. This is a key message. From the Maya themselves, one might hope for more local enterprise and less speed in sending the best and brightest to the cities.

The government does best when it provides an infrastructure of health care, education, and easy road access. These, taken together, have proved valuable in allowing the Maya of central Quintana Roo to take much more control of their own fate in the wider world. Isolated villages like Presidente Juarez provide the counterpoint; with notably less good access to these three things, they have had serious difficulties in accessing markets and improving lifeways.

Capital was a serious limit on agricultural improvement 20 years ago, but from the early 1990s limitations were eased, except during the recession of 1993-94. Local people always able to come up with just enough capital, thanks to the extended family. Everyone has a relative with a good job somewhere. Individual families do run short of cash, especially after frequent hurricanes and droughts. Micro-lending could be improved in the area. The Mexican government's intricate and extensive bureaucracy, including segmentation of effort and problems for clients in accessing support, puts hurdles in the way of start-up businesses, and this is an enormous disincentive to enterprise.

As noted above, the government's plans usually founder on one rock: Marketing. This is a common failing of government schemes and NGO plans everywhere in the world. The Maya, by contrast, are amazingly good at finding the tiniest niche market that will actually pay. In other parts of Latin America,

15 The senior author was sure of getting good service for his Nissan car in Chetumal, the nearest city, because the head of the repair shop at the Nissan dealership was a Chunhuhub Xool. 
where Maya and other local communities produce products of global importance, international NGOs that focus on marketing have really helped local communities. This is true in regard to coffee, cacao, Guatemalan Maya weavings, and other products (see e.g. Jaffee 2007 for coffee; see Ellerman 2005 and Stiglitz and Charlton 2005 for the general case). Too often in the Yucatán world, questions of profitability are seldom raised. Similar stories of Maya vs. outside development abound (Faust et.al. 2004).

Meanwhile, the state of Quintana Roo develops with considerable speed, but the development is almost entirely in the realm of tourism, and the capital comes largely from outside. With full cooperation from the Mexican state and many of its ministers, giant international hotel chains, fuel suppliers, restaurant franchises, and other corporations have occupied a lot of land and buildings, and account for much of the state's 'development'. Tourism resorts depend largely on food, fuel, and other goods from outside Quintana Roo and usually from outside the country. The profits are largely repatriated out of México. Resorts interface with the Maya largely by hiring villagers as construction workers, chambermaids, and other unskilled laborers.

The Quintana Roo government has recently expanded development southward from Cancun (Fig. 1), and is now focusing on developing the coast due east of Chunhuhub, a previously underdeveloped area. This will take the pressure off Cancun, and bring many more opportunities to the Chunhuhub area. On the other hand, it is yet another development that could concentrate economic activity on the coast and turn the interior into a mere labor reserve. One can easily imagine a better fate: an ecotourism project in Chunhuhub (similar to ones already common elsewhere on the Yucatán Peninsula), with local foods, local handicrafts, local medicines, local forest products, and so on, to give the adventurous tourist a real sense of Maya life. This need not be the sort of crass commercialization seen in many such schemes. If much of the planning were left to local people, they would see to that.

As an example, the canny villagers of Tulum have been particularly successful at winning tourists and tourist dollars, beating many international entrepreneurs at their own game. The tourism center of Playa del Carmen has turned into something of a Quintana Roo Maya capital, with major education centers, employment opportunities, government agencies, and more. These successes show that the facilitation given to giant corporations, if targeted at the Maya instead of the multinationals, would probably have produced a bit less value, but the wealth would have stayed in the region.

The people who have dealt with a difficult environment for 3,000 years are not yet broken by the new problems of outside interference and rapid urbanization. And some Maya are rapidly getting better formal education, and finding more jobs in the higher sectors of the labor force.

\section{The political economy of development}

Many communities, in México as in the US and elsewhere, have developed a certain amount of cynicism about government planning in general. The government is perceived as bringing in a great new plan just before an election, handing out money to carry out the project, and then canceling the project once the election is over. Typically, the plan is just fine as long as some funding is coming in, but otherwise is not profitable enough to be worth doing. A few iterations of this game lead to the situation reported by Ueli Hostettler (1996): the villagers invest the donated money in beer and have a party. Otherwise, the money is invested, then lost when the government abruptly cancels the project, half done. All this has caused many people in Quintana Roo, as in other areas from American inner cities to African savanna villages, to suffer from project fatigue. ${ }^{16}$

These tales can be matched from around the world (Anderson 2010b; Dichter 2003; Ellerman 2005; Hancock 1991; Juhasz 2008; Stiglitz 2003). Since WWII, billions of dollars have been spent on development. Some $\$ 60$ billion are now spent every year (Dichter 2003:104). There is now widespread admission that the money spent has not solved the problems it targeted (Dichter 2003; Stiglitz 2003; cf. studies in Faust et.al. 2004). Anthropologists have also carried out countless studies showing how foolish outside developers are, and how smart the locals are at surviving in spite of them (Tanya Li's The Will to Improve, 2007 sums up a vast literature).

Thomas Dichter (2003) points out that part of the problem lies in the way development assistance is done. Complex and often byzantine bureaucracies invoke complex and expensive procedures, often badly targeted. Mistakes amplify through the system. There are the usual problems of bureaucracy-lack of accountability, and top-down control by out-of-touch administrators. Dichter sees the rise of a huge international development industry as the root of the problem. Certainly, the data in the present paper support his conclusions. David Ellerman (2005) finds similar problems, and stresses the need for the kind of grassroots reality-testing we have emphasized.

There are too many signs that the agencies know all too well what they are doing to the world economy, and continue to do it anyway (cf. Ascher 1999). The world does little about the trade barriers invoked by the

\footnotetext{
${ }^{16}$ For more forthright views of development in the Yucatán Peninsula, see Frazier (2004) and Hostettler (1996).
} 
rich nations against the poor ones (Stiglitz 2003). Above all, farm subsidies are enormous in the richer nations. The United States gives every American farmer an average of \$57,000 a year in direct payouts, and at least as much again in indirect support. Almost all of this goes to the giant agribusiness firms, not to small farms. European subsidy levels are similar. México has given every advantage to giant multinational firms, in agribusiness as in tourism and other areas. This impacts the Maya directly. They are maize farmers, and formerly sold the crop commercially, but subsidized maize from the United States was cheap enough to make this unprofitable. Now, maize prices are high, because of subsidies for biofuel production that have led to diversion of $40 \%$ of United States maize to that market (Biello 2011). This would help the Maya if a large surplus could now be produced, but the above-noted climate deterioration has prevented that for several years. Instead, Maya who do not produce adequate maize for subsistence now have to pay prices much higher than in previous years. The subsidy economy produces an unstable maize economy worldwide, and this affects even subsistence or near-subsistence producer. On the other hand, heavy subsidies in the United States and México to oil firms sometimes make agricultural fuel and chemicals more cost effective.

This point is devastating to most received wisdom about neoliberalism. Few authors have noticed that the game is not 'free trade' or 'reducing government' as the philosophy of neoliberal reform would indicate. The game is forcing cutthroat local competition on the poorer and smaller nations while heavily subsidizing the giant multinational firms and giving them every governmental and international-agency advantage (Anderson 2010b). The playing field was not level in any case; a Maya farmer is hardly going to compete with an American seed firm. But, increasingly, competition is between 'free markets' in the global south and multinational firms so heavily subsidized that they are virtual or actual parastatals (detailed documentation is provided in Anderson 2010b).

Fortunately, México is more aware than many countries of the need to improve people's lives through overall wealth creation. Education is universal and quite good. An educated workforce is obviously more able to do hi-tech jobs, design and produce new inventions, and go into high-value-added enterprises. Also, rising wages force companies to modernize and become more efficient, to keep other costs down in the face of rising labor costs (Hayami and Ruttan 1985). Money for more education has to come from somewhere; it is part of the nation's labor cost. But, as México is aware, an unskilled workforce is even more expensive when opportunity costs are figured into the equation.

\section{Conclusion}

At present, Chunhuhub is being pulled in three directions. These are emblematic of the process of change in similar regions that are gradually being incorporated in to neoliberal economies. One pull factor is that many are leaving for the cities. Others are taking advantage of new agricultural opportunities to develop security of tenure and invest in orchards and livestock, based on centuries of local deployment of knowledge and skill. Others are moving into town occupations: stores, government work, and the service sector. If we use Western agricultural communities as an analog, what do we learn? There are countless small ghost towns in the United States and Europe that have been emptied by rural restructuring. Perhaps many of them deserved the fate. Farm work, especially for landless laborers, is hard, wearing, and often a ticket to nowhere, and we do not particularly regret the fate of many dead-end farm towns. But we do not believe that Chunhuhub and the other Maya towns deserve this. The people there are dynamic, hard-working, and thoughtful. They have shown a capacity to adapt to climatic and other hazards, and 'develop' on their own terms. They deserve better than to become maids and day laborers in urban centres. Moreover, all attempts to develop the Quintana Roo forest and landscape by capital-intensive, large-scale, technologically highly sophisticated operations have failed, so far. The rocky soils, variable climate, and pest problems ensure that there is no likelihood of success without the intensive knowledge of the environment that the Maya have. The more successful schemes we have outlined above all include strong local input and modification to local conditions.

Market-driven agricultural and economic development schemes need to provide real local benefits, rather than allowing those to accrue externally and to powerful actors (see Ervine 2011 in this issue, on Chiapas). A recent evaluation of over 11,000 World Bank development projects showed that those with conservation goals were as successful at producing economic development as those that ignored conservation and simply went for the money (Kareiva et.al. 2008). The one common denominator that all successful plans have, and that none of the failed schemes reported here have, is that they actually give opportunities to ordinary people. It is among the ordinary people of the world that we can, and must, seek and find salvation. 


\section{References}

Alexander, Rani T. 2006. Maya settlement shifts and agrarian ecology in Yucatán, 1800-2000. Journal of Anthropological Research 622:449-470.

Anderson, B.A.; E. N. Anderson; T. Franklin; A Dzib-Xihum de Cen. 2004. Pathways of decision making among Yucatán Mayan traditional birth attendants. Journal of Midwifery and Women's Health 49(4): 312319.

Anderson, Barbara. 2011. The nursing workforce shortage: the vulnerability of the healthcare system. In Mary de Chesnay and Barbara Anderson (eds.), Caring for the vulnerable. $3^{\text {rd }}$ edn. Burlington, MA: Jones and Bartlett Learning. Pp. 557-563.

Anderson, E.N. 2003. Those who bring the flowers. Chetumal: ECOSUR.

--- 2005. Political ecology in a Yucatec Maya community. Tucson: University of Arizona Press.

--- 2010a. Managing Maya commons: Quintana Roo, Mexico. In L.M. Johnson and E.S. Hunn (eds.), Landscape ethnoecology: concepts of biotic and physical space. New York: Berghahn. Pp. 25-276.

--- 2010b. The pursuit of Ecotopia. Santa Barbara: Praeger.

Anderson, E.N, and F. Medina Tzuc. 2005. Animals and the Maya in Southeast Mexico. Tucson: University of Arizona Press.

Arellano Rodríguez, J. Alberto; José Salvador Flores Guido; Juan Tun Garrido; María Mercedes Cruz Bojórquez. 2003. Nomenclatura, forma de vida, uso, manejo y distribución de las especies vegetales de la Península de Yucatán. Mérida: Universidad Autónoma de Yucatán. Etnoflora Yucatánense no. 20.

Ascher, William. 1999. Why governments waste natural resources. Baltimore: Johns Hopkins University Press.

Atran, Scott. 1993. Itza Maya tropical agro-forestry. Current Anthropology 34: 633-700.

Atran, Scott; Douglas Medin; Norbert Ross; Elizabeth Lynch; John Coley; Edilberto Ucan Ek; Valentina Vapnarsky. 1999. Folkecology and commons management in the Maya lowlands. Proceedings of the National Academy of Sciences 96: 7598-7603.

Atran, Scott; Ximena, Lois; Edilberto Ucan Ek'. 2004. Plants of the Petén Itza' Maya. Ann Arbor: University of Michigan, Museum of Anthropology, Memoir 38.

Baños Ramírez, Othón. 1989. Yucatán: ejidos sin campesinos. Mérida: Universidad Autónoma de Yucatán.

--- (ed.). 1990. Sociedad, estructura agraria y estado en Yucatán. Mérida: Universidad Autónoma de Yucatán.

Benitez, Fernando. 1986. Ki: El drama de un pueblo y una planta. $2^{\text {nd }}$ edn. (orig. 1956). Mexico City: Fondo de Cultura Económica.

Bernard, H. Russell. 2006. Research methods in anthropology. $3^{\text {rd }}$ edn. Lanham, MD: AltaMira (Rowman and Littlefield).

Biello, David. 2011. The false promise of biofuels. Scientific American, Aug., pp. 59-65.

Bray, David Barton; Leticia Merino-Pérez; Deborah Barry (eds.). 2005. The community forests of Mexico: managing for sustainable landscapes. Austin: University of Texas Press.

Buckles, Daniel. 1995. Velvetbean: a 'new' plant with a history. Economic Botany 49:13-25.

Demarest, Arthur. 2004. Ancient Maya: the rise and fall of a rainforest civilization. Cambridge: Cambridge University Press.

Dichter, Thomas W. 2003. Despite good intentions: why development assistance to the third world has failed. Amherst \& Boston: University of Massachusetts Press.

Ellerman, David. 2005. Helping people help themselves: from the World Bank to an alternative philosophy of development assistance. Ann Arbor: University of Michigan Press.

Escamilla, Alfredo; Mauro Sanvicente; Miguel Sosa; Carlos Galindo-Leal. 2000. Habitat mosaic, wildlife availability, and hunting in the tropical forest of Calakmul, Mexico. Conservation Biology 14:1592-1601.

Ervine, Kate. 2011. Conservation and conflict: the intensification of property rights disputes under marketbased conservation in Chiapas, México. Journal of Political Ecology 18: 66-80.

Faust, Betty B. 1998. Mexican rural development and the plumed serpent. Westport, CT: Greenwood.

Faust, Betty B.; E. N. Anderson; John G. Frazier (eds.). 2004. Rights, resources, culture, and conservation in the land of the Maya. Westport, CT: Greenwood.

Fedick, Scott (ed.). 1996. The managed mosaic: Ancient Maya agriculture and resource use. Salt Lake City: University of Utah Press. 
Ford, Anabel, and Kitty Emery (eds.). 2008. Exploring the legacy of the Maya forest. Journal of Ethnobiology 28:2:147-153.

Foster, George. 1966. Peasant society and the image of limited good. American Anthropologist 67:293-315.

Frake, C.O. 1980. Language and cultural description: essays by Charles O. Frake. Ed. Anwar S. Dil. Stanford: Stanford University Press.

Frazier, John G. 2004. The "Yucatán Syndrome": its relevance to biological conservation and anthropological activities. In Betty Faust, E. N. Anderson and John G. Frazier (eds.), Rights, Resources, Culture, and Conservation in the Land of the Maya. Westport, CT: Greenwood. Pp. 225-254.

Freese, Curtis H. (ed.). 1997. Harvesting wild species: implications for biodiversity conservation. Baltimore, MD: Johns Hopkins University Press.

Gladwin, Christina. 1989. Ethnographic decision tree modeling. Newbury Park, CA: Sage.

Gómez-Pompa, A., M.F. Allen, S.L. Fedick and J.J. Jiménez-Osornio (eds.). 2003. The lowland Maya area: three millennia at the human-wildland interface. New York: Haworth Press.

Greenberg, Laurie S. 1992. Garden hunting among the Yucatec Maya: a coevolutionary history of wildlife and culture. Etnoecologica 1:1:23-33.

Haenn, Nora. 2005. Fields of power, forests of discontent. Tucson: University of Arizona Press.

Hancock, Graham. 1991. Lords of poverty. London: MacMillan.

Hayami, Yujiro, and Vernon Ruttan. 1985. Agricultural development. Baltimore: Johns Hopkins University Press.

Herrera Castro, Natividad. 1994. Los huertos familiares Mayas en el oriente de Yucatán. Etnoflora Yucatánense \#9. Mérida: Universidad Autónoma de Yucatán.

Hostettler, Ueli. 1996. Milpa Agriculture and economic diversification: socioeconomic change in a Maya peasant society of Central Quintana Roo, 1900-1990s. PhD in Ethnology, University of Bern.

Humphreys, Macartan; Jeffrey D. Sachs; Joseph E. Stiglitz (eds.). 2007. Escaping the resource curse. New York: Columbia University Press.

Jaffee, Daniel. 2007. Brewing justice: fair trade coffee, sustainability, and survival. Berkeley: University of California Press.

Juhasz, Antonia. 2008. The tyranny of oil: the world's most powerful industry-and what we must do to stop it. New York: William Morrow (HarperCollins).

Kareiva, Peter; Amy Chang; Michelle Marvier. 2008. Development and conservation goals in World Bank Projects. Science 321:1638-1639.

Keys, E. 2004. Chili cultivation in the Southern Yucatán region: plant-pest disease as land degradation. Land Degradation and Development. 15(4): 397-409.

Kintz, Ellen. 1990. Life under the tropical canopy: tradition and change among the Yucatec Maya. New York: Holt, Rinehart, Winston.

Klooster, D. 1999. Community-based forestry in Mexico: can it reverse processes of degradation? Land Degradation and Development. 10(4): 363-379.

Li, Tanya Murray. 2007. The will to improve. Durham: Duke University Press.

Marín Martínez, Columba, Leonor Sosa Jarquín, Miguel Chan y Pat, Juventino Ortega, and Bernarndina Góngora Tun. 2008. Much' meyajtik maaya ts'aak: Manual de remedios prácticos para una vida saludable, Chunhuhub Q Roo. Mexico City: ADMITE, S.C

Martinez Reyes, José. 2004. Contested place, nature, and sustainability: a critical anthropo-geography of biodiversity conservation in the 'Zona Maya' of Quintana Roo, Mexico. Ph.D. dissertation, Dept. of Anthropology, University of Massachusetts-Amherst.

Mathews, Jennifer. 2009. Chicle: the chewing gum of the Americas from the Ancient Maya to William Wrigley. Tucson: University of Arizona Press.

McAnany, Patricia A., and Tomás Gallareta Negrón. 2010. Bellicose rulers and climaological peril? Retrofitting twenty-first-century woes on eighth-century Maya society. In McAnany, Patricia A. and Norman Yoffee (eds.). Questioning collapse: human resilience, ecological vulnerability, and the aftermath of Empire. Cambridge: Cambridge University Press. Pp. 142-175.

McAnany, Patricia A., and Norman Yoffee. 2010. Questioning collapse: human resilience, ecological vulnerability, and the aftermath of Empire. Cambridge: Cambridge University Press.

Painter, Michael, and William Durham (eds.). 1995. The social causes of environmental destruction in Latin America. Ann Arbor: University of Michigan. 
Perramond, Eric P. 2008. The rise, fall and reconfiguration of the Mexican ejido. Geographical Journal 98: 356-371.

Primack, Richard B., David Bray, Hugo A. Galletti and Ismael Ponciano (eds.). 1998. Timber, tourists and temples: conservation and development in the Maya forest of Belize, Guatemala, and Mexico. Washington, DC: Island Press.

Redclift, Michael. 2004. Chewing Gum: the fortunes of taste. London: Routledge.

Redfield, Robert, and Alfonso Villa Rojas. 1934. Chan Kom, a Maya village. Carnegie Institution of Washington.

Sharer, Robert J., and Loa Traxler. 2005. The Ancient Maya. $6^{\text {th }}$ edn. Stanford: Stanford University Press.

Simonian, Lane. 1995. Defending the land of the jaguar: a history of conservation in Mexico. Austin: University of Texas Press.

Staller, John, and Miachael Carrasco (eds.). 2010. Pre-Columbian foodways: interdisciplinary approaches to food, culture, and markets in Ancient Mesamerica. New York: Springer.

Stiglitz, Joseph E. 2003. Globalization and its discontents. New York: W. W. Norton.

Stiglitz, Joseph E. and Andrew Charlton. 2005. Fair trade for all: how trade can promote development. Oxford: Oxford University Press.

Terán, Silvia, and Christian H. Rasmussen. 1993. La milpa de los Mayas. Mérida: authors.

Terán, Silvia; Christian H. Rasmussen; Olivio May Cauich. 1998. Las plantas de la milpa entre los Mayas. Mérida: Fundación Tun Ben Kin.

Toledo, Victor M., Narciso Barrera-Bassols, Educard García-Frapolli and Pablo Alarcón-Chaires. 2008. Uso múltiple y bidiversidad entre los Mayas Yucatecos (México). Interciencia 33:345-352.

Turner, B.L., II; Peter Klepeis; Laura C. Schneider. 2003. Three millennia in the Southern Yucatán peninsula: implications for occupancy, use, and carrying capacity. In A. Gómez-Pompa, M. F. Allen, S. L. Fedick and J. J. Jiménez-Osornio (eds.), The lowland Maya area: three millennia at the human-wildland interface. New York: Food Products Press, an imprint of Haworth Press. Pp. 361-388.

Tuxill, John, Luis Arias Reyes, Luis Latournerie Moreno, Vidal Cob Uicab and Devra I. Jarvis. 2010. All maize is not equal: maize variety choices and Mayan foodways in rural Yucatán, Mexico. In John Staller and Michael Carrasco (eds.), Pre-Columbian foodways: interdisciplinary approaches to food, culture, and markets in ancient Mesoamerica, New York: Springer. Pp. 467-486.

Webster, David. 2002. The fall of the Ancient Maya. New York: Thames and Hudson.

Whitmore, Thomas M., and B. L. Turner II. 2001. Cultivated landscapes of Middle America on the eve of conquest. New York: Oxford University Press.

Wright, Lori. 2006. Diet, health, and status among the Pasión Maya: a reappraisal of the collapse. Vanderbilt Institute of Mesoamerican Archaeology Series, vol. 2. Nashville: Vanderbilt University Press.

\begin{abstract}
Maya agriculture is currently outperforming alternatives across the Yucatán Peninsula, while changing to incorporate new ideas that fit with its basic commitment to shifting agriculture based on maize as the staple and over 100 minor crops. Considerable research over the last 60 years has shown the reasons for agricultural resilience, which include thorough understanding of the Yucatán environment and use of a range of resources and techniques that allow fine-tuning in particular situations while remaining flexible overall. Development efforts have usually failed in this environment, which has shallow and fragile soils and suffers from frequent droughts, typhoons, and pest outbreaks. The predictor of development success is usually supply and demand: where there is a market, the Maya will work to develop supply capability; where there is no market, traditional subsistence methods are better than the introductions. Government or international help is, however, needed to help develop markets and to provide expert knowledge of how to mobilize for them and connect to them. When this has been done, some important successes have followed. A current problem is the international subsidy economy. Neoliberalism in the Maya context involves a reduction of government help to local and small-scale enterprises while large-scale multinational firms are given enormous direct and indirect subsidies by their home governments and by commodity-producing nations. The resulting unfair competition is a block on development. Actual free markets-in the sense of local grassroots enterprise being given something like a level playing field—could be an improvement.
\end{abstract}

Key words: Maya; neoliberalism; Indigenous agricultural knowledge; access to markets 


\section{Résumé}

L'agriculture Maya est actuellement surperformant des alternatives à travers la péninsule du Yucatán, tout en changeant d'incorporer de nouvelles idées qui conviennent à son engagement de base pour l'agriculture itinérante basée sur le maïs et plus de 100 cultures. Des recherches considérables au cours des 60 dernières années a montré les raisons de résilience agricoles, qui incluent la compréhension approfondie de l'environnement du Yucatán et l'utilisation d'une gamme de ressources et de techniques qui permettent de réglage fin dans des situations particulières tout en restant flexible. Les efforts de développement rurale ont généralement échoué dans cet environnement, qui a des sols peu profonds et fragile qui souffre de sécheresses fréquentes, les typhons et les infestations de ravageurs. Le prédicteur de la réussite du développement est généralement l'offre et la demande: où il va un marché, les Mayas s'attachera à développer la capacité d'approvisionnement: où il n'va pas de marché. les méthodes traditionnelles de subsistance sont mieux que les techniques venant de l'exterieur. Le gouvernement ou de l'aide internationale est, cependant, nécessaire pour aider à développer des marchés et à fournir des connaissances d'expert sur la façon de se mobiliser et se connecter. Lorsque cela a été fait. d'importants succès ont suivi. Un problème actuel est l'économie de subvention internationale. Le néolibéralisme dans le contexte de Mava implique une réduction de l'aide gouvernementale aux entreprises locales et à petite échelle tandis que les grandes enterprises multinationales sont donnés des subventions énormes, directes et indirectes, par leurs gouvernements et par les producteurs de 1eme monde. La competition resultant est un bloc sur le développement. Un marché réelle, - bénéficiant d'entreprise locale de base et égalitaire - pourrait être une amélioration.

Mots clés: Maya; néolibéralisme; connaissances agricoles, l'accès aux marches

\section{Resumen}

La agricultura maya está actualmente desarrollando alternativas a lo largo de la península de Yucatán, al incorporar nuevas ideas que se adaptan con su compromiso básico con la agricultura migratoria basada en el maíz como alimento básico y otros 100 cultivos menores. Investigaciones importantes durante los últimos 60 años han mostrado las razones que sustentan el enfoque de la resiliencia en la agricultura, la cual incluye una exhaustiva comprensión del entorno en Yucatán, así como el uso de una amplia variedad de recursos y técnicas que permiten un perfeccionamiento en situaciones específicas, mientras que en general, permanecen flexibles. Los esfuerzos de desarrollo comúnmente han fracasado en este entorno, el cual presenta suelos frágiles y con poca profundidad, al mismo tiempo que sufre de frecuentes sequías, tifones y brotes de plagas. Los premonitores de éxito de desarrollo son generalmente la oferta y la demanda, donde exista el mercado los mayas trabajarán para poder satisfacer dicha capacidad de suministro; donde no exista tal, los métodos de subsistencia tradicionales serán mejor opción que los introducidos. Sin embargo, la ayuda gubernamental o internacional es necesaria para ayudar a desarrollar mercados y para proveer conocimiento especializado en temas relacionados a movilidad y conectividad. Cuando esto ha ocurrido, algunos importantes casos de éxito han derivado del proceso. Un problema actual es la economía de subsidio internacional. El Neoliberalismo en el contexto Maya representa una reducción de la ayuda gubernamental a los pequeños productores locales, mientras que a grandes compañías multinacionales se les otorgan y destinan considerables subsidios, de forma directa o indirecta, por parte de los gobiernos de origen, así como de naciones productoras. La resultante competencia injusta, representa un obstáculo para el desarrollo.

Palabras clave: Maya, neoliberalismo. Agricultura indígena, acceso a mercados. 